\title{
ERRATUM
}

Sibel Eyigor · Simin Hepguler · Kazim Capací

\section{A comparison of muscle training methods in patients with knee osteoarthritis}

Published online: 18 February 2004

(C) Clinical Rheumatology 2004

\section{Clin Rheumatol (2004)}

DOI 10.1007/s10067-003-0836-9

The names of the second and third authors of this contribution were inadvertently not published. They are now provided above.

The online version of the original article can be found at http:// dx.doi.org/10.1007/s10067-003-0836-9

S. Eyigor $(\bowtie) \cdot S$. Hepguler · K. Capací

Physical Therapy and Rehabilitation Department,

Ege University Medical Faculty,

35100 Bornova, Izmir, Turkey

E-mail: eyigor@hotmail.com 